\title{
Pedestrian democracy and the geography of hope
}

\author{
Kevin Gray* \\ Professor of Law and Dean of Trinity College, Cambridge, UK; Professor of Law, National University of \\ Singapore
}

A notable feature of the contemporary evolution of property law has been an increasing recognition of public entitlements of access to wild or scenic natural landscape. The right to traverse someone else's land for recreational purposes is one component of what some have called 'pedestrian democracy'. The following pages trace the origin of liberalizing developments in this area, relating these innovations to the paucity and fragility of preexisting entitlements of recreational user. But can it now be said that there exists a human right of access to nature? This article addresses some of the arguments that might underlie such a claim. It explores the nexus between moral landscape, aesthetic experience, personal and psychological well-being, social equity, citizenship and environmental responsibility. The paper draws upon convergent themes in law, literature and landscape theory in order to identify the 'geography of hope' which Wallace Stegner famously associated with the proximity and accessibility of raw earthscape. The article concludes by suggesting that the modern paramountcy of environmental obligation is beginning to import a correlative human right to engage more closely with the natural world and to enjoy access to the regenerative benefits afforded by wild and open spaces.

Keywords: access, scenic landscape, human rights, rationales of entitlement

\section{INTRODUCTION}

Most of us are pedestrians. Some of us may even be democrats. This paper examines one of the modern intersections of these two initially rather different kinds of personal descriptor. The central concern of the paper is the moral, social and legal ecology of scenic natural landscape. Its underlying theme is the way in which, in a wider distribution of the goods of citizenship, the concept of property is currently being reconfigured to afford novel public rights of recreational access to wild or open country. This extension of access rights over privately held land articulates one increasingly significant component of the civic republican ideal, a virtue that some have called 'pedestrian democracy'. The purpose of the present paper is to indicate why 'pedestrian democracy' - in this case the self-determining, self-empowering, self-fulfilling entitlement of the citizen to walk or climb over natural terrain - may be considered both necessary and important in the 21 st century. It matters not whether pedestrian access takes the form of an airy scramble up a mountain or a leisurely amble along a rural or coastal track. Nor are the relevant issues localized in one jurisdiction.

* For valuable advice and assistance, thanks are owed to Alice Goodman, Susan Francis Gray and Claire Sladden. An early version of this paper benefited from helpful discussion at a Faculty Workshop held at Cornell Law School on 25 April 2008. 
They have a shared provenance in the comparative law of human property rights in respect of the natural environment.

The inescapable problem is, of course, that natural landscape tends to belong to someone else. Realty is, in this sense, a scarce resource. Even if the earth's total land surface were today divided equally between the world's population, each man, woman and child on the planet would be allotted an area measuring less than 150 metres by 150 metres. ${ }^{1}$ Within the densely inhabited United Kingdom this notional personal allocation is reduced to a space of just over 60 metres by 60 metres. Any meaningful recreational access inevitably requires substantial incursion into the land of others. Herein lies the difficulty: claims to non-consensual entry upon a stranger's territory touch immediately on one of the raw nerves of common law jurisprudence. In the Anglo-American-Australasian tradition the right to exclude unwanted intruders is conventionally regarded as 'one of the most essential sticks in the bundle of rights that are commonly characterized as property'. ${ }^{2}$ Some have therefore argued that the law of recreational access should be founded on the broad recognition of a superior or lexically prior human right of enjoyment of nature. ${ }^{3}$ Nowadays, however, the reality may be that interaction with the natural environment has become - for many reasons - more akin to a human responsibility than a human right.

Although the issue of bipedal freedom to experience the outdoors is not without its difficulties, the liberating process under discussion in this paper is closely associated with an Olmstedian vision of the civic dividend and personal vitality to be derived from shared recreational access to open spaces. ${ }^{4}$ '[I]n Wildness', said Henry David Thoreau, "is the preservation of the World. ${ }^{5}$ Wildness is, of course, in somewhat short supply in the crowded urbanized communities of Western Europe and may therefore comprise a highly relative concept. ${ }^{6}$ But, as the American writer and environmentalist Wallace Stegner astutely recognized, 'the wilderness idea ... is a resource in itself'. He added that '[w]ithout any remaining wilderness we are committed, without chance for even momentary reflection and rest, to a headlong drive into our technological termite-life, the Brave New World of a completely man-controlled environment'. ${ }^{7}$ In a fractured, rootless and demoralized society, the ready availability of access to the world of nature provides, in Stegner's celebrated phrase, 'a means of

1. Based on the world's population as indicated by the US Census Bureau at 11:53 on 27 August 2009 (www.census.gov/main/www/popclock.html).

2. Kaiser Aetna v US 444 US 164, 176, 62 L Ed 2d 332, 344 (1979) (Rehnquist J). On the significance of 'excludability', see KJ Gray, 'Property in Thin Air' [1991] Cambridge LJ 252, 268-9.

3. The late Neil MacCormick suggested that the freedom of movement guaranteed by Protocol No 4, Article 2 of the European Convention on Human Rights implicitly supports a general right of 'access to hills, mountains, waterways and open countryside' (N MacCormick, 'An Idea for a Scottish Constitution' in W Finnie, CMG Himsworth and N Walker (eds), Edinburgh Essays in Public Law (Edinburgh University Press, Edinburgh 1991) 168, 180).

4. See RF Nash, Wilderness and the American Mind (Yale University Press, New Haven and London 1967) 106-7.

5. 'Walking' in HD Thoreau, Excursions (George G Harrap \& Co, London 1914) 177.

6. 'Wilderness is a relative condition' (A Leopold, 'Wilderness as a Form of Land Use' (1925) in SL Flader and JB Callicott (eds), The River of the Mother of God (and Other Essays by Aldo Leopold) (University of Wisconsin Press, Madison 1991) 135).

7. W Stegner, 'Coda: Wilderness Letter' (3 December 1960) in R Finch and J Elder (eds), Nature Writing: The Tradition in English (WW Norton \& Co, New York and London 2002) 515. 
reassuring ourselves of our sanity as creatures, a part of the geography of hope' ${ }^{8}$ The English poet Geoffrey Hill speaks similarly of 'moral landscape' as 'a terrain seen in cross-section ... in which particular grace, individual love, decency, endurance, are traceable across the faults'?

It is precisely this connection between environment, humanity, morality and civic entitlement which the present paper seeks to explore.

\subsection{A century of change}

Tempora mutantur nos et mutamur in illis - times change and we change with them. In 1905 the English Court of Appeal felt obliged to condemn in damages (albeit fairly nominal damages) a group of trespassers who had trodden paths along the rocky cliffs of a privately owned portion of beautiful Cornish coastline. ${ }^{10}$ While conceding that the owner's denial of access was 'churlish' and 'unreasonable', the Court was clear that the defendants had failed to establish any claim of right or justification for their intrusion. Moreover, said Buckley $\mathbf{J}$ (in recitation of a sentiment frequently expressed by judges of that era), '[n]othing worse can happen in a free country than to force people to be churlish about their rights for fear that their indulgence may be abused'. ${ }^{11}$ Except in special cases, therefore, access to privately owned scenic space was strictly permissive and the landowner's exclusory power both total and totalitarian. ${ }^{12}$

What a difference a century makes! By the time the present paper appears in print it is confidently expected that royal assent will have been given to the Marine and Coastal Access Bill 2009. This legislation will require, over the next ten years, the creation of a new long-distance walking route 'allowing two people to walk comfortably abreast' along a virtually continuous four metre-wide access corridor around the entire 4,000 kilometres of English coastline. ${ }^{13}$ In permitting this extensive right of foot traverse to override existing land titles, the current Labour government intends to reinforce the proposition that 'free access to its coastline should be the birthright of an island race'. ${ }^{14}$ The Bill explicitly refers to 'the desirability of [the] route adhering to the periphery of the coast and providing views of the sea' ${ }^{15}$ The official vision is of 'a coastal environment where rights to walk along the length of the English coast lie within a wildlife and landscape corridor that offers enjoyment, understanding of the natural environment and a high quality experience'. ${ }^{16}$

8. Ibid 519 .

9. 'The Triumph of Love' (1998) in G Hill, Selected Poems (Penguin Books, London 2006) 185.

10. Behrens $v$ Richards [1905] 2 Ch 614.

11. Ibid 619-20. See also Blount v Layard [1891] 2 Ch 681n, 691 (Bowen LJ).

12. See generally KJ Gray and S Francis Gray, 'Civil Rights, Civil Wrongs and Quasi-Public Space' (1999) 4 EHRLR 46, 52-5.

13. Marine and Coastal Access Bill (HL Bill 137), Part 9. See Natural England, Coastal Access: Natural England's outline scheme (April 2008), paras 2.1.1, 4.3.8. The public will also have access to a 'coastal margin' or area of 'spreading room' along the shore.

14. Consultation on Proposals to improve access to the English coast (Department for Environment, Food and Rural Affairs, June 2007), para 8.3.

15. Marine and Coastal Access Bill, cl 292(2)(b). See Natural England, Coastal Access (n 13), paras 4.4.1, 4.5.1.

16. Consultation on Proposals to improve access to the English coast (n 14), para 2.1; Draft Marine Bill (Policy Paper) (Cm 7351, April 2008), Annex 4 (Coastal Access Impact Assessment), para 12; Marine and Coastal Access Bill Policy Document (Department for Environment, Food and Rural Affairs, Updated December 2008), para 15. 


\subsection{The democratization of property}

When enacted, the Marine and Coastal Access Bill will complement and expand the so-called 'right to roam' provisions introduced by the Countryside and Rights of Way Act 2000. The CROW Act (as it is widely known) came fully into effect in October 2005 and confers on every member of the public an unprecedented right 'to enter and remain ... for the purposes of open-air recreation' on any 'access land' situated in England and Wales. ${ }^{17}$ This is not the place to describe the detailed operation of the Act, ${ }^{18}$ save to say that, subject to certain exceptions, 'access land' is defined as land located more than 600 metres above sea level, together with other specifically mapped areas of 'open country' (ie land consisting 'wholly or predominantly of mountain, moor, heath or down'), registered common land, and land irrevocably dedicated by the owner to public access. ${ }^{19}$ Rights of entry are limited to access on foot (although at all hours of day and night) and are conditional on reasonable and responsible user of the countryside. ${ }^{20}$ It has been estimated that the CROW Act underwrites a general access entitlement to something approaching $12 \%$ of the total land area of England and Wales. ${ }^{21}$

It is readily apparent that modern statute law is turning on its head much of the historic disinclination to recognize public rights of access to privately owned scenic landscape. ${ }^{22}$ Despite the occasional grumble that not much, if anything, is 'won' through the passing of such legislation, ${ }^{23}$ it seems tolerably plain that significant steps have been taken toward the 'democratization of property'. In the postmodern age one of the transformative movements in contemporary property theory entails, not the classic Marxian reduction of economically pivotal goods to collective ownership, but rather the guarantee of rights of general civic access to socially desired opportunities and facilities. The 'new property' - perhaps not quite that envisaged by Charles Reich for 'rootless twentieth century man' ${ }^{24}$ - involves the endorsement of various sorts of communal easement on behalf of the people. ${ }^{25}$ As Crawford Macpherson once pointed out, the idea of property is being gradually broadened to include a 'right to a kind of society or set of power relations which will enable the individual

17. Countryside and Rights of Way Act 2000, s 2(1).

18. See KJ Gray and S Francis Gray, Elements of Land Law (5 $5^{\text {th }}$ edn OUP, Oxford 2009), paras 10.7.47-10.7.50.

19. CROW Act 2000, ss 1(1)-(2), 16.

20. CROW Act 2000, s 2(1)(b), Sch 2.

21. Access to the Open Countryside in England and Wales (Department of Environment, Transport and the Regions Consultation Paper, February 1998), para 3.10. Legislation covering Scotland goes even further than the CROW Act 2000. It confers a right of entry upon land for recreational and other purposes which is not restricted (as under the CROW Act) to defined or specifically mapped areas of 'access land', but is applicable to all land in Scotland subject only to certain express exclusions (see Land Reform (Scotland) Act 2003, ss 1(1)-(3), 6).

22. Arden LJ has spoken of 'a rebalancing of private and social interests in land ... a sea change in the law's approach to the rights of members of the public to the reasonable enjoyment of the English countryside' (R (Ashbrook) v East Sussex County Council [2002] EWCA Civ 1701 [48]).

23. G Parker and N Ravenscroft, 'Land, Rights and the Gift: The Countryside and Rights of Way Act 2000 and the Negotiation of Citizenship' (2001) 41(4) Sociologia Ruralis 381, 394.

24. CA Reich, 'The New Property' (1964) 73 Yale LJ 733, 787.

25. See, however, JL Anderson, 'Britain's Right to Roam: Redefining the Landowner's Bundle of Sticks' (2007) 19 Geo Int'l Envtl L Rev 375, 434 (noting that, during the passage of the CROW Bill, certain parliamentary critics derided its provisions as 'the product of a society verging on socialism'). 
to live a fully human life' ${ }^{26}$ Indeed, some claim that we have now entered an era in which the ideology of access has become 'a potent conceptual tool for rethinking our world view as well as our economic view'. On this basis, access has emerged as 'the single most powerful metaphor of the coming age'. ${ }^{27}$

\section{THE NECESSITY FOR 'PEDESTRIAN DEMOCRACY' - A HIATUS OF LEGAL ENTITLEMENT}

It is possible that in England there was once a 'golden age' which acknowledged some generalized right of access to privately held land for purposes of travel and recreation. Over the centuries there is certainly strong evidence of a network of ancient ways and footpaths, many of which survive to the present day, facilitating journeys between isolated communities or pilgrimage to sacred locations. In medieval times there may even have been an acceptance of some early form of the right to roam over open uncultivated land, but any entitlement of this kind was gradually extinguished, from the 16th century onwards, by the enclosure movement. The dim recollection of such entry as of right has been said merely to reflect 'the gulf which existed between the medieval historian and the modern lawyer' ${ }^{28}$

For the most part recreational access to the land of others came to rest on remarkably fragile foundations. There is little English authority dealing explicitly with the question of common law rights of non-consensual public access to open country. Quite simply, the issue has seemed so clear that for at least 250 years nobody has seriously thought to suggest the persistence at common law of any universally enforceable entitlement to enter another's land for recreational purposes. Certain special cases apart, ${ }^{29}$ most recreational resort has tended to comprise some form of tolerated trespass or entry under summarily revocable licence. ${ }^{30}$ Even by 1673 Vaughan CJ was able to declare that 'to hunt in a man's park' was merely an action 'which, without license, had been unlawful'. ${ }^{31}$

26. CB Macpherson, 'Capitalism and the Changing Concept of Property' in E Kamenka and RS Neale (eds), Feudalism, Capitalism and Beyond (Australian National University Press, Canberra 1975) 120.

27. J Rifkin, The Age of Access: How the Shift from Ownership to Access is Transforming Capitalism (Penguin Books, London 2000) 15.

28. Loder v Gaden (1999) 78 P \& CR 223, 239 (Brooke LJ).

29. In England and Wales certain limited rights of public access to the countryside have been conferred by a fragmented range of statutory and other initiatives (as, for example, by the National Parks and Access to the Countryside Act 1949 and through the presumed dedication of footpaths under the Highways Act 1980) and by certain common law doctrines relating to local customary right and presumptions of long-lost grant. See TJ Bonyhady, The Law of the Countryside: the Rights of the Public (Professional Books, Abingdon 1987); Gray and Gray (n 18), paras 10.7.34-10.7.45.

30. It is trite law that a bare licence confers no proprietary or possessory entitlement on the entrant (Thomas $v$ Sorrell (1673) Vaugh 330, 351, 124 ER 1098, 1109), but merely ensures that he cannot be treated as a trespasser. As Martin B trenchantly announced in Bolch $v$ Smith (1862) 7 H \& N 736, 745-6, 158 ER 666, 669-70, '[i]f I avail myself of permission to cross a man's land, I do so by virtue of a licence, not of a right. It is an abuse of language to call it a right.' See likewise Winter Garden Theatre (London) Ltd v Millennium Productions Ltd [1948] AC 173, 188 (Viscount Simon).

31. Thomas $v$ Sorrell (1673) Vaugh 330, 351, 124 ER 1098, 1109. See also Wood v Leadbitter (1845) 13 M \& W 838, 844, 153 ER 351, 354 (Alderson B). 
The 18th century brought resounding endorsements of the idea that 'every invasion of land, be it ever so minute, is a trespass. No man can set his foot upon my ground without my licence' ${ }^{32}$ Certainly, when in the late 19th century some of the citizens of Keswick claimed an historic customary right of access to Latrigg Hill (an outlier of Skiddaw and a local beauty spot), a strong Court of Appeal was adamant that the alleged entitlement could be supported, if at all, only by evidence that the landowner had positively dedicated the walking route up the hill as a public highway. ${ }^{33}$

\subsection{Extremely limited rights of recreational user in England and Wales}

The conclusion to be drawn from any historical survey is clear. Prior to the commencement of the CROW Act 2000, the law of England and Wales conferred on members of the public only extremely limited rights of recreational user in respect of land and water, ${ }^{34}$ albeit that substantial de facto access was undoubtedly enjoyed in a somewhat ill-defined way. ${ }^{35}$ The common law recognized no expansive version of recreational access by custom ${ }^{36}$ or under some doctrine of public trust ${ }^{37}$ (as in certain parts of the United States). Still less did the law incorporate anything approaching the Swedish Allemansrätt, that is, a general entitlement of access on foot, horseback, skis or cycles to privately held land. However incongruously, the common law regarded areas of mountain, hill, crag, moorland, coastline and non-tidal water as the equivalent of any other category of privately owned land. The law of access has thus been dominated by the same concepts of trespass and licensed entry that apply in the very different context of, say, the family home and its immediate curtilage. As an English judge announced fairly recently, it is 'not part of the normal function of a private landowner to provide facilities for the public on the land' ${ }^{38}$ In the

32. Entick v Carrington (1765) 19 Howell's State Trials 1029, 1066 (Lord Camden CJ). Another report of the same case quotes the Chief Justice as saying that '[o]ur law holds the property of every man so sacred, that no man can set his foot upon his neighbour's close without his leave' ((1765) 2 Wils KB 275, 291, 95 ER 807, 817).

33. Spedding v Fitzpatrick (1888) 38 Ch D 410 (Cotton, Fry and Lopes LJJ).

34. Likewise Scots law traditionally recognized no right of unconsented recreational access to another's land (Earl of Breadalbane v Livingston (1790) M 4999, as aff'd (1791) 3 Pat 221; Dyce v Lady James Hay (1852) 1 Macq 305, 312-5), although in practice the recreational visitor was left largely immune from legal sanction (see KGC Reid, The Law of Property in Scotland (Butterworths, Edinburgh 1996), para 182).

35. Indeed the liberality of de facto recreational access in England and Wales was frequently attributed to a broadly shared consensus that licences of reasonable access could never mature into, or be confused with, entitlements of access. During much of the last century courts were consistently anxious not to construct rights of access from 'acts of kindly courtesy' lest this should 'drive landowners to close their gates in order to preserve their property' (Attorney-General v Antrobus [1905] 2 Ch 188, 199 (Farwell J)).

36. See Marsh v Colby 39 Mich 626, 627 (1878); McKee v Gratz 260 US 127, 136, 67 L Ed 167, 170 (1922) (Holmes J); State ex rel Thornton v Hay 462 P2d 671, 676-7 (1969); Stevens v City of Cannon Beach 854 P2d 449, 456-7 (Or 1993), cert den 510 US 1207, 127 L Ed 2d 679 (1994).

37. Matthews and Van Ness v Bay Head Improvement Ass'n 471 A2d 355, 365-6 (1984); Raleigh Ave Beach Ass'n v Atlantis Beach Club, Inc 879 A2d 112, 119-21 (NJ 2005); Bubis $v$ Kassin 960 A2d 779, 783-7 (NJ 2008). See GS Alexander, 'The Social Obligation-Norm in American Property Law' (2009) 94 Cornell L Rev 745, 801-7.

38. $R$ (Beresford) $v$ Sunderland CC [2001] 1 WLR 1327 [45] (Smith J). 
result, there is no universal common law right to ramble over open countryside. ${ }^{39}$ The supposed 'freedom of the hills' is nothing more than an aspirational or rhetorical flourish, connoting no legal entitlement in respect of upland areas. There is, similarly, no public right at common law to walk upon the foreshore or to have access to the seashore for the purpose of swimming or other recreation. ${ }^{40}$ In all such contexts the enjoyment of access has usually been based on some strained implication of licensed entry ${ }^{41}$ or on a tolerated user in respect of which the landowner by long tradition - in most cases - has sought no remedy in trespass.

\subsection{A doctrinal rationale}

One reason for the resistance to any generalized common law entitlement of recreational access is highly conceptual in origin, but is no less significant for being so. English law has traditionally refused, in all but the most anomalous contexts, ${ }^{42}$ to acknowledge the juristic phenomenon of the ius spatiandi (ie a right to wander at will over an undefined open space held in the proprietorship of another person). ${ }^{43}$ Such an entitlement is simply not a species of right known to the common law and cannot therefore be acquired through either private grant or prescriptive user. ${ }^{44}$ The rationale for this position is the strong belief that such an unqualified and wide-ranging form of entitlement is exactly the sort of right which the landowner enjoys over his own land. Indeed, it is the unrestricted nature of the owner's right to go precisely where he pleases on his land which symbolizes the essence of a freehold or leasehold estate. ${ }^{45}$ The ius spatiandi violates the orderly schematic canon that delineates the recognized entitlements of the common law of realty. All of which merely underscores the innovative character of recent and current legislation on access to recreational space. Statutes such as the CROW Act 2000 breathe life into a form of entitlement

39. See Earl of Coventry $v$ Willes (1863) 9 LT 384, 385; Hammerton $v$ Honey (1876) 24 WR 603, 604.

40. Blundell v Catterall (1821) 5 B \& Ald 268, 294, 299-300, 303-4, 106 ER 1190, 1200-3; Brinckman v Matley [1904] 2 Ch 313, 324; Williams-Ellis v Cobb [1935] 1 KB 310, 320-1; Alfred F Beckett Ltd v Lyons [1967] Ch 449, 482E-F; Adair v National Trust for Places of Historic Interest or Natural Beauty [1998] NI 33, 41j.

41. A tolerated trespass can sometimes shade, by virtue of the landowner's acquiescence, into an implied licence (see Lowery $v$ Walker [1910] 1 KB 173, 195-6; Canadian Pacific Railway Co $v$ The King [1931] AC 414, 424, 428 (Lord Russell of Killowen)).

42. See eg Re Ellenborough Park [1956] Ch 131.

43. This distaste for iura spatiandi is echoed in many other jurisdictions (see eg Stevens $v$ Headley 62 A 887, 892 (NJ Ch 1905); Randwick Corpn v Rutledge (1959) 102 CLR 54, 74; Drye v Eagle Rock Ranch, Inc 364 SW2d 196, 208-9 (1963); Smeltzer v Fingal CC [1998] 1 IR 279, 286; Murphy v Wicklow CC (Irish High Court, 19 March 1999); Kanak v Minister for Land and Water Conservation (NSW) (2000) 180 ALR 489, 497).

44. International Tea Stores Co v Hobbs [1903] 2 Ch 165, 172; Attorney-General v Antrobus [1905] 2 Ch 188, 198-9 (Farwell J); Re Ellenborough Park [1956] Ch 131, 184 (Evershed MR). See Skrenty v Harrogate BC (Chancery Division, 26 October 1999) ('it might be more than a little presumptuous for me not to follow Antrobus').

45. See Attorney-General v Antrobus [1905] 2 Ch 188, 208, where a claim of public right to visit and wander around the megalithic monument at Stonehenge was castigated as 'simply extravagant' and as an attempt 'to dispossess the [landowner] of his property' for which no 'serious argument' could be adduced. 
inconceivable at common law - a universal right of self-determining pedestrian access to land - creating thereby a statutory ius spatiandi.

\section{THE IMPORTANCE OF 'PEDESTRIAN DEMOCRACY' - THE GEOGRAPHY OF HOPE}

If the common law tradition offers only the most fleeting support for public rights of access to the recreational outdoors, the question still poses itself why, in the 21 st century, such entitlements should be regarded as important. What social or moral traction can be claimed by the cause of 'pedestrian democracy'? To this challenge a number of varied responses present themselves. In sum, they take the form of an assertion that active recreational engagement with the natural environment is today not simply some kind of optional experiential bonus or extra, but has become - perhaps always was vital for the survival and flourishing of the civil and ecological communities of which we humans are a part. The issue is one not of election, but of prudential necessity. The social and legal space constituted by wild or open country is intimately bound up in a complex web of factors and perceptions relating to environmental responsibility, public health, personal and psychological well-being, aesthetic sensibility, historic memory, sense of place, citizenship, human right, distributive equity and social inclusion.

The central message is that natural landscape is not ethically neutral - it has a deeply moral dimension. It is, as Wallace Stegner said, 'a part of the geography of hope'. It is therefore significant that the modern statutory promotion of public access entitlements in the British countryside has been driven by some recognition of the values implicit in 'pedestrian democracy' and of the social and moral benefits to be derived from the realization of this civic goal. But, in precisely this respect, today's legislator has simply arrived rather late at the understanding so eloquently expressed two millennia ago by the Roman poet, Virgil: 'fortunatus et ille deos qui novit agrestis' (blest too is he who knows the rural gods). ${ }^{46}$

This is not, of course, to say that in more recent times the business of walking across open country has been overlooked as a valuable, healthy, even overtly political form of activity. Wordsworth, Coleridge and Ruskin are well known to have roamed the Cumbrian fells. ${ }^{47}$ The Pantheon of the North American wilderness tradition is dominated by those who, like Henry Thoreau, expounded the 'art of Walking' and saw 'every walk [as] a sort of crusade'. ${ }^{48}$ John Muir undertook his memorable thousand-mile walk to the Gulf $^{49}$ and many similar treks. Decades later Muir described his daily immersion in nature in a journal entry which recorded that he 'only went out for a walk, and finally concluded to stay out till sundown, for going out, I found, was really going in' ${ }^{50}$ The physical process of ambulation assumes a different, and even more serious, dimension when employed as a means of voicing political protest or dissent. In 1965 the march of thousands of people from Selma to Montgomery made history and, in conjunction with

46. Georgics II 493 (TF Royds (tr), Eclogues and Georgics (Dent, London 1946) 115).

47. See generally MH Nicolson, Mountain Gloom and Mountain Glory: The Development of the Aesthetics of the Infinite (Cornell University Press, Ithaca NY 1959) 388-93.

48. 'Walking' in Thoreau (n 5) 154-5.

49. J Muir, A Thousand-Mile Walk to the Gulf (ed by WF Badè, Houghton Mifflin Co, Boston and New York 1916).

50. LM Wolfe (ed), John of the Mountains: the Unpublished Journals of John Muir (Houghton Mifflin Co, Boston and New York 1938) 427. See Nash (n 4) 122-40. 
the impassioned oratory of Martin Luther King, changed the face of the United States for ever. ${ }^{51}$ On an admittedly lesser scale, the mass trespass of 1932 at Kinder Scout in Derbyshire (together with its vicious suppression) proved influential in launching a nationwide ramblers' movement and ultimately found its full vindication in the enactment of the CROW Act 2000.

At any level and no matter how trivial the expedition, the activity of bipedal locomotion across landscape is always important. Rebecca Solnit reminds us that walking is 'the intentional act closest to the unwilled rhythms of the body, to breathing and the beating of the heart ... a state in which the mind, the body, and the world are aligned'. For Solnit, 'the mind is also a landscape of sorts and ... walking is one way to traverse it'. ${ }^{52}$ A closely related aspect of ambulatory experience was articulated by the poet, Edwin Muir. Muir wrote of walking as taking on 'the appearance of a pilgrimage' perhaps because it prompts 'some deep archetypal image in our minds of which we become conscious only at the rare moments when we realize that our own life is a journey'. ${ }^{53}$ And everything said here about ambulation is, of course, equally applicable to mountaineering and rock climbing, which are species of ambulation distinguished only by the degree of incline, technical difficulty and personal risk involved.

\subsection{Citizenship, distributive equity and social inclusion}

One of the multi-stranded elements inherent in the concept of 'pedestrian democracy' relates to themes of citizenship, civic equality and distributive equity. Carol Rose may possibly have overstated the point some years ago when she reflected a view that 'unique recreational sites ought not to be private property'. ${ }^{54}$ Nevertheless strong arguments of equity tend toward the conclusion that access to wild or scenic open country and the non-commodity values which such locations represent should not be the exclusive preserve of the privileged few. Beautiful and irreplaceable wild areas should be left reasonably available for beneficial enjoyment by all, a proposition which finds support in embryonic doctrines of stewardship or quasi-public trusteeship, ${ }^{55}$ the mandate of "prime necessity' ${ }^{56}$ and the historic classification of certain privately held assets as property 'affected with a public interest'. ${ }^{57}$ Thus, for many, a violation of some kind of proprietary morality is implicit in the fact that Quinag, an exceptionally fine mountain in Sutherland, was once presented as a wedding gift

51. R Solnit, Wanderlust: A History of Walking (Verso, London 2002) 59.

52. Ibid 5-6.

53. E Muir, An Autobiography (Hogarth Press, London 1954) 217.

54. CM Rose, 'The Comedy of the Commons: Custom, Commerce, and Inherently Public Property' (1986) 53 U Chi L Rev 711, 780.

55. KJ Gray, 'Equitable Property' (1994) 47(2) CLP 157, 188-206.

56. A common law doctrine of 'prime necessity' emerged some time ago (see Attorney General of Canada $v$ Toronto (1893) 23 SCR 514, 520; Minister of Justice for the Dominion of Canada v City of Lévis [1919] AC 505, 513) and has recently been revitalized in New Zealand (see Vector Ltd v Transpower New Zealand Ltd [1999] 3 NZLR 646 [35]-[51], [77]; Sky City Auckland Ltd v Wu [2002] 3 NZLR 621 [25]-[26]). The doctrine requires that certain valued commodities controlled by monopoly suppliers which are 'indispensable for the preservation of the public health' are therefore held on trust 'for the benefit of the general public' and must be made available on terms which are 'fair and reasonable'.

57. See Gray and Gray (n 12) 85-6. 
by one member of the landed aristocracy to another. ${ }^{58}$ Substantial collective doubt inevitably surrounds the ethical status of large vestings of scenic space in relatively small numbers of private owners. When in the early 1990s there was a threat that several hundred square kilometres of wilderness in North West Scotland would be effectively closed to walkers and climbers by their businessman-owner, a veritable army of outdoors enthusiasts united (successfully) behind the credo that 'You can't own a mountain: it belongs to everybody'. ${ }^{59}$

Shared access as of right to scenic natural terrain also engenders a heightened sense both of civic responsibility and of participation in an integrative society of equals. It was Justice William O Douglas of the United States Supreme Court who wrote of the 'citizenship of the mountains' where '[p]overty, wealth, accidents of birth, social standing, race [are] immaterial' ${ }^{60}$ The social dividends of the outdoor experience can indeed be political in nature. We are not far here from the Jeffersonian ideal of the 'virtuous citizen' who lives in close communion with the land. ${ }^{61}$ For Douglas the earthscape of mountains, forests, lakes and coastlines called forth and epitomized important qualities of freedom and equality and, as Charles Reich once observed, if the encounter with wild country 'nurtures the democratic character', then the frustration of access to the natural environment 'may properly be seen as a civil liberties issue, ${ }^{62}$

The civic sentiments and the political philosophy disclosed in such views clearly transcend national boundaries. It is noticeable that the access provisions of recent or imminent legislation in Britain have been explicitly premised on the perceived imperative of 'promoting social inclusion'63 and 'reducing social divisions' ${ }^{64}$ The introduction of this legislation has mobilized the rhetoric of civic integration, particular reference being made to the need to "increase the participation in outdoor recreation of certain under-represented groups - black and ethnic minority communities, the young, the disabled and the socially disadvantaged'. ${ }^{65}$ Government has effectively given its conclusive endorsement to the idea that '[p]eople expect access to the countryside ... for enjoyment as part of their civic rights' ${ }^{66}$ The consultation process which preceded the passage of the CROW Act 2000 pointedly recognized that, as a matter of 'social equity', it was 'right that all our citizens should be able to enjoy quiet recreation by walking in some of our finest countryside. Access to this part of our common heritage is something which should be enjoyed by the many, not the few' ${ }^{67}$ This emphasis on civic entitlement begins to instantiate, at least in one

58. J MacAskill, We Have Won The Land (Acair, Stornoway 1999) 38.

59. The story is told in KJ Gray, 'The Ambivalence of Property' in G Prins (ed), Threats without Enemies (Earthscan Publications, London 1993) 153-4.

60. WO Douglas, Of Men and Mountains (Gollancz, London 1951) 211, 293.

61. See JB Jackson, 'Jefferson, Rousseau, and After' in HL Jackson (ed), Landscape in Sight: Looking at America (Yale University Press, New Haven and London 1997) 175-82.

62. CA Reich, 'The Individual Sector' (1990-91) 100 Yale LJ 1409, 1445.

63. Scottish Executive, Draft Land Reform (Scotland) Bill: Consultation Paper (February 2001), para 1.5. For identical references to the importance of social inclusion, see Draft Marine Bill (Policy Paper) (n 16), Annex 4, para 11.

64. Access to the Open Countryside in England and Wales (n 21), para 3.50.

65. Consultation on Proposals to improve access to the English coast (n 14), Annex A, para 5.10.

66. Draft Marine Bill (Policy Paper) (n 16), Annex 4, para 7. There is 'a widespread perception that the public has a right to access beaches and the foreshore' (ibid, para 4).

67. Access to the Open Countryside in England and Wales (n 21), para 3.67. 
limited respect, the ratification accorded by the Stockholm Declaration of 1972 to a 'fundamental right to freedom, equality and adequate conditions of life, in an environment of a quality that permits a life of dignity and well-being .... ${ }^{68}$

\subsection{Personal well-being and psycho-social connection}

Another extremely significant factor in the modern movement toward 'pedestrian democracy' has been a growing acknowledgement of the beneficial personal and psychological effect of encounters with nature and wild country. An influential school of economists now concedes that environmental values must be taken into account in measuring the quality of life and human well-being. ${ }^{69}$ At an empirical level there has long been evidence of the restorative consequences of contact with natural landscape. ${ }^{70}$ But the impact of personal exposure to untamed scenic terrain is increasingly recognized in more holistic terms that encompass all aspects of an individual's physical, psychological and moral welfare.

This awareness of the therapeutic or regenerative value of the walk through nature can be expressed in a hundred different ways and with varying overtones of transcendental or spiritual connotation. Even the most hardened atheist can attest to the humanizing and socializing qualities of engagement with the natural environment. Percy Bysshe Shelley, for example, had no difficulty in announcing his call to a place in 'the universal sun' where, briefly at least, 'all things seem only one':

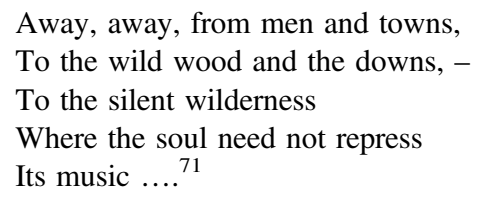

Most of us can even make the leap to an assessment of moral value. High and open places lend a certain moral elevation. ${ }^{72}$ Abstracted from the cloying complexities of busy urban life, it is difficult on the mountain top or in the deserted country lane not to sense the possibility of a life of greater virtue, purity and simplicity. Adapting a line of Ben Jonson, Henry Thoreau was able to proclaim 'How near to good is what

68. Declaration of the United Nations Conference on the Human Environment (UN Doc A/ Conf.48/14/Rev 1) (1972) 4 (Principle 1). See also D Shelton, 'Human Rights, Environmental Rights, and the Right to Environment' (1991-92) 28 Stan J Int'l L 103; C Miller, Environmental Rights: Critical Perspectives (Routledge, London 1998) 1-2; A Dobson, Citizenship and the Environment (OUP, Oxford 2003) 90-1.

69. P Dasgupta, Human Well-Being and the Natural Environment (OUP, Oxford 2001). See also A Berleant, Living in the Landscape: Toward an Aesthetics of Environment (University Press of Kansas, Lawrence 1997) 37-9.

70. RS Ulrich, 'Visual Landscapes and Psychological Well-Being' (1979) 4(1) Landscape Res 17; WL Parry-Jones, 'Natural landscape, psychological well-being and mental health' (1990) 15(2) Landscape Res 7.

71. PB Shelley, 'To Jane: The Invitation' (1822) in T Hutchinson (ed), Shelley: Poetical Works (OUP, Oxford 1967) 668-9.

72. There is some deep sense in which the mountain-top experience makes us more decent human beings. On the transcendental aspects of exposure to wilderness, see Gray (n 55) 199-202. On the emerging links between natural law theory and 'ecological morality', see further J Holder, 'New Age: Rediscovering Natural Law' (2000) 53 CLP 151. 
is wild' ${ }^{73}$ Yet much of the literature of landscape concerns itself with the sheer bounty to be enjoyed through contemplation of natural beauty. '[I]n every walk with Nature one receives far more than he seeks', wrote John Muir. ${ }^{74}$ Alexander Pope preferred the 'amiable simplicity of unadorned Nature' to the 'nicer Scenes of Art' on the ground that the former induced 'a more noble sort of Tranquility, and a loftier Sensation of Pleasure' ${ }^{75}$ It was Wordsworth who was largely responsible for introducing the perception that 'the proper way of communing with nature is by walking through the countryside' ${ }^{76}$ If nothing else, ambulation is conventionally associated with meditation - thinking 'at three miles an hour' ${ }^{77}$ Jean-Jacques Rousseau professed himself unable to think except when walking ${ }^{78}$ an intellectual connection historically exemplified by the so-called school of Peripatetic philosophers in ancient Athens (who paced up and down while teaching) and by writers such as Søren Kierkegaard. ${ }^{79}$

This nexus between ambulation and cogitation introduces us to a further dimension of the wholesome impact of engagement with the natural environment - a dimension that imparts an extended meaning to the phrase 'environmental health'. The pedestrian traverse of scenic landscape is also an exploration of the country of the mind. It is about self-discovery, the quest for meaning and significance, about locating oneself in time and place amidst what is often otherwise a rootless existence. Walking is not simply a method of enlarging terrestrial experience; it is a journey into the solitude of the soul (whether this last term be understood in a religious sense or not). A distancing from this experience can entail wistful, ineffable loss: AE Housman's 'blue remembered hills' represented 'the land of lost content ... the happy highways where I went and cannot come again'.80

Kenneth Olwig has written, illuminatingly, of the etymology of the word country, relating it to basic connotations of that which is opposite or contrary. ${ }^{81}$ Olwig traces the roots of country to the late Latin contrata (literally, 'those things which are situated opposite the beholder'). Similarly, the German Gegend (in the sense of a region or tract of country) incorporates a radical meaning of 'counter'. Thus, for Olwig, is mobilized the metaphor of the mirror - the idea that 'what is opposite oneself comes to include oneself' - that visual engagement with landscape reflects back inner truths about oneself. External landscape becomes the counterpart of an inner landscape, affording a locus in which environmental connection is both self-identifying and self-constituting. ${ }^{82}$

Certainly this analysis sits easily beside much landscape literature which emphasizes the constant perceptual interaction between the viewer and that which is

73. 'Walking' in Thoreau (n 5) 179. To place this quotation in historical context, see KR Olwig, Landscape, Nature, and the Body Politic: From Britain's Renaissance to America's New World (University of Wisconsin Press, Madison 2002) 183.

74. Steep Trails (Sierra Club Books, San Francisco 1994) 92 (first published 1918).

75. See A Pope, 'Essay from The Guardian' in JD Hunt and P Willis (eds), The Genius of the Place: The English Landscape Garden, 1620-1820 (MIT Press, Cambridge MA 1988) 205.

76. M Shoard, This Land Is Our Land: The Struggle for Britain's Countryside ( $2^{\text {nd }}$ edn Gaia Books, London 1997) 79.

77. Solnit (n 51) 14.

78. JM Cohen (tr), The Confessions (Penguin Books, Harmondsworth 1953) 382.

79. Solnit (n 51) $15,23$.

80. AE Housman, A Shropshire Lad (1896) XL.

81. Olwig (n 73) 240.

82. KJ Gray, 'Foreword' in J Holder and D McGillivray (eds), Locality and Identity: Environmental Issues in Law and Society (Ashgate Publishing Ltd, Aldershot 1999) 11. 
viewed. ${ }^{83}$ Landscape, said Yi-Fu Tuan, is 'an image, a construct of the mind and of feeling ... an ordering of reality from different angles' ${ }^{84}$ For Denis Cosgrove, landscape was 'a way of seeing the world', the affective dimension of landscape indicating 'a harmony between human life and the milieu in which it is lived'. ${ }^{85}$ Arcadia is 'precisely a place where the relationship between human society and the natural world is opened for critical reflection'. ${ }^{86}$ In the famous phrase of Howard Zahniser (the prime mover in the United States of the Wilderness Act 1964), 'the true wilderness experience is one, not of escaping, but of finding one's self by seeking the wilderness' ${ }^{87}$ Entry upon natural terrain offers a vade mecum to a promised land where there are occasional epiphanous moments of perfected vision and heightened understanding. Walking the earth is a means of coming to peace with life and of making sense of the world. ${ }^{88}$ If nothing else, as John Passmore said, the encounter with nature on any large scale 'helps to preserve men from hubris'. The refreshment and enjoyment to be found in wandering through wild country is ' $[\mathrm{n}]$ ot only recreation, but re-creation; it renews one's sense of proportion'. ${ }^{89}$

It is ultimately a matter of individual persuasion or conviction whether, or to what degree, one invests such environmental experience with spiritual content. ${ }^{90}$ Some, like George Macaulay Trevelyan, have been content to refer in restrained tones to the walker's 'reward in the repossession of his own soul'. ${ }^{91}$ In his splendidly naïve way John Muir acknowledged that '[e]verybody needs beauty as well as bread, places to play in and pray in, where Nature may heal and cheer and give strength to body and soul'. ${ }^{2}$ Walking afforded John Finley 'an intimacy with the sacred things and the primal things of earth that are not revealed to those who rush by on wheels' ${ }^{93}$ Indeed, for centuries the ultimate spiritual journey has taken the form of pilgrimage on foot.

83. In writing about 'an intimate bond of person and place' and an 'interpenetration of landscape and experience', Arnold Berleant describes an aesthetic engagement that 'rejects the traditional separation of viewer and object in favor of their total absorption in environment' (Berleant (n 69) 23, 35-6).

84. Y-F Tuan, 'Thought and Landscape: The Eye and the Mind's Eye' in DW Meinig (ed), The Interpretation of Ordinary Landscapes (OUP, New York 1979) 89-90.

85. DE Cosgrove, Social Formation and Symbolic Landscape (University of Wisconsin Press, Madison 1998) 13, 17.

86. DE Cosgrove, Geography and Vision: Seeing, Imagining and Representing the World (IB Tauris \& Co, London and New York 2008) 73.

87. H Zahniser, 'The Need for Wilderness Areas' (1956-57) 59 The Living Wilderness 37, 43 (Winter-Spring).

88. Heightened awareness of mortality in Arcadia is, of course, the subject of Nicholas Poussin's Et in Arcadia Ego. See S Schama, Landscape and Memory (Alfred A Knopf, Inc, New York 1994) 517-9; Cosgrove (n 86) 75-6.

89. J Passmore, Man's Responsibility for Nature ( $2^{\text {nd }}$ edn Duckworth, London 1980) 106-7. 90. For an extreme example, see JC Nagle, 'The Spiritual Values of Wilderness' (2005) 36 Envtl Law 955. See generally CJ Glacken, Traces on the Rhodian Shore: Nature and Culture in Western Thought from Ancient Times to the End of the Eighteenth Century (University of California Press, Berkeley 1967).

91. 'Walking' in EV Mitchell (ed), Pleasures of walking: an anthology of works by Belloc, Dickens, Trevelyan, Beerbohm and others (Spurbooks, Bourne End 1979) 58 (first published 1934).

92. 'The Hetch Hetchy Valley' in J Muir, The Yosemite (Century Company, New York 1912) 256.

93. J Finley, 'Traveling Afoot' in Mitchell (ed) (n 91), 17. 
Much of the great North American wilderness writing of the 19th century was, of course, infused by a transcendentalist form of 'moral environmentalism'. ${ }^{44}$ As European expansion into the western states opened up their landscape treasures, the mystic qualities of wilderness inspired a more profound theistic awareness. ${ }^{95}$ Confronted by the majesty of the unfolding west, Ralph Waldo Emerson claimed to 'see all; the currents of the Universal Being circulate through me; I am part or particle of God'. ${ }^{96}$ After surviving a stormy night in the open on Oregon's Mount Hood on the journey westward, Sarah Cummins looked out next morning over a 'panorama of beauty with which my soul was entranced ... I was lost in infinity' ${ }^{97}$ Back in Europe 'mountain gloom' had long been displaced by perceptions of 'mountain glory'. ${ }^{98}$ The 'delightful horror" ${ }^{99}$ of wild places and steep chasms had given way to romanticism, the Grand Tour and a new philosophy of the sublime. ${ }^{100}$ But it was left to Justice William O Douglas to capture, perhaps better than anyone else, the spiritual quality of the encounter with raw nature. Speaking of the high country of his adopted Washington State, Douglas wrote that in 'the silence and solitude of the mountains in wintertime ... man comes closer to God ... He finds the inner harmony that comes from communion with the heavens. He can draw strength from the austere, majestic beauty around him'. ${ }^{101}$

Whether or not one shares such spiritual reflections, there is a further abstract or cerebral aspect of landscape experience that is important for the psycho-social wellbeing of the modern citizen. In a world of constant dislocation and discontinuity brought about by the demands of educational opportunity, career mobility, family responsibility and much else - there has been a generalized loss of any 'sense of place'. Geographical roots and participation in long-term community have largely withered away. Self-perceptions of identity and connectedness have been weakened; the historic memory of belonging and integration has greatly diminished. Yet a regular engagement with a world of natural beauty can be an effective means of preserving certain fixed reference-points that impart a degree of permanence, locality, continuity and security to an ever-changing existence. Thus, for example, James Trombley is able to extrapolate from 'an organic identification with place' to a 'tacit understanding between subject and object whereby the environment is designated as both source and reflection of basic human values'. ${ }^{102}$ For the Victorian Leslie Stephen, walks were 'the unobtrusive connecting thread of other memories'. Each

94. RF Nash, 'Aldo Leopold's Intellectual Heritage' in JB Callicott (ed), Companion to A Sand County Almanac: Interpretive \& Critical Essays (University of Wisconsin Press, Madison 1987) 64.

95. Cosgrove (n 85) 185.

96. RW Emerson, 'Nature' (1836) in J Porte (ed), Ralph Waldo Emerson: Essays \& Lectures (The Library of America, New York 1983) 10.

97. SJ Cummins, Autobiography and Reminiscences (Walla Walla, Wash 1914) 46, quoted by A Kolodny, The Land Before Her: Fantasy and Experience of the American Frontiers, 16301860 (University of North Carolina Press, Chapel Hill and London 1984) 240.

98. Nicolson (n 47) 345, 368-9.

99. Schama (n 88) 447. See generally Nash (n 4).

100. Cosgrove (n 85) 226-9; D Cosgrove and V della Dora, 'High Places' in D Cosgrove and V della Dora (eds), High Places: Cultural Geographies of Mountains, Ice and Science (IB Tauris \& Co, London 2009) 5.

101. Douglas (n 60) 278. See Gray (n 55) 201-2.

102. JA Trombley, "“A Simultaneous and Joined Identity": The Eco-communitarian Ideal in Wallace Stegner's American West' (2005) 13 Cercles 25, 27-9. 
walk is "naturally interwoven with all the thoughts, the friendships, and the interests that form the staple of ordinary life'. ${ }^{103}$ It may even be - in some paradoxical fashion - that an embrace of the geographical unknown provides the key to psychological strength, personal orientation and ultimate self-awareness. This is TS Eliot's 'way of dispossession', expressed in lines which could easily be an allegory of the serious recreational walker's personal experience of traversing unfamiliar territory:

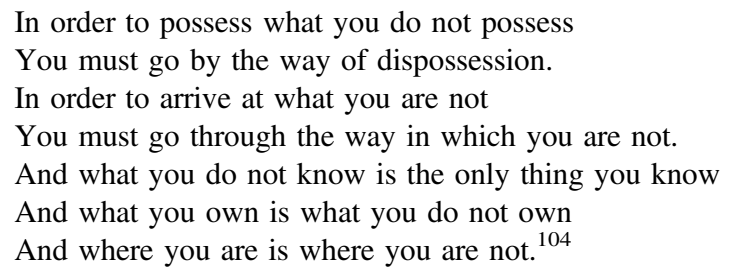

It is quite clear that in Britain recent legislative initiatives relating to the expansion of recreational access rights have been motivated, in part, by an appreciation of the deeply personal benefits conferred by exposure to the natural environment. It could not, of course, be expected that the explanatory and consultation materials outlining various government proposals would detail these benefits in the particularly moral or spiritual terms discussed in the paragraphs above. But it is significant that recurring reference has been made - in more secular language - to the role of outdoors activity in promoting good mental hygiene and balanced personal adjustment. The Consultation Paper preceding the introduction of the CROW Bill declared that walking 'can provide real benefits to people's physical and mental well-being', by enabling citizens to 'experience the wonders of wildlife and the beauty of fine landscapes' and 'to refresh their spirits' ${ }^{105}$ Some people would 'savour the peace and quiet of remote areas'; others would wish 'to test their powers of endurance in the harshest conditions they can find'. ${ }^{106}$ Under an explicit reference to 'mental health' the same Consultation Paper concluded that walking is 'an antidote to the pressures of modern life'. ${ }^{107}$ Improvements to 'quality of life' were likewise promised as the outcome of the analogous Scots legislation. ${ }^{108}$ Similar sentiments now underlie the proposal of a continuous long-distance coastal walking path in England. The benefits of coastal access rights 'will include the improved health and well-being that access to the natural environment has been shown to bring' and will extend to 'benefits from improved psychological health'. ${ }^{109}$ The government has expressly recognized that 'people value the natural environment for the cultural, spiritual and recreational benefits it provides'. 110

103. L Stephen, 'In Praise of Walking' in Mitchell (ed) (n 91) 20.

104. TS Eliot, 'East Coker' (1940) 140-146, in The Four Quartets (Faber and Faber, London 1959).

105. Access to the Open Countryside in England and Wales (n 21), Foreword and para 1.8.

106. Ibid, para 3.66 .

107. Ibid, para 3.67.

108. Scottish Executive, Draft Land Reform (Scotland) Bill (n 63), para 1.5.

109. Draft Marine Bill (Policy Paper) (n 16), Annex 4, para 24, Annex A3.1. This Policy Paper contains further reference to 'personal well-being through access to the natural environment' (Annex 4, para 11).

110. Ibid, Annex 4, para 7. 


\subsection{Public health concerns}

An almost inseparable component of the motivation toward recreational access legislation in Britain has been an increasing concern for the sheer physical health of the general population, although this rather prosaic rationale is not unconnected with a perceived need to reduce the fiscal burdens falling upon the nation's health services. The unwelcome prospect of an ageing and physically inactive population has become a major driver of policy and planning. Some years ago the Labour government declared its aim of ensuring by 2020 that $70 \%$ of the population is reasonably physically active. ${ }^{111}$ One means of achieving this goal lies in the provision of enhanced opportunities for the ordinary citizen to get heart, lungs and legs pumping away in moderate physical exertion. The CROW Act 2000 was explicitly promoted in terms of 'the benefits to society as a whole' that would be conferred by 'wandering in the countryside', particular reference being made to the gains in physical health and quality of life likely to be achieved through wholesome exercise. ${ }^{112}$ Like aspirations accompanied the enactment of the equivalent access legislation in Scotland. ${ }^{113}$ The imminent promise of a coastal access entitlement in England has been associated with the assertion that '[r]egular physical activity is recognised as playing a role in preventing some illnesses and in ameliorating some existing illnesses' ${ }^{114}$ However improbably, the 'social benefit' per person of moving from a sedentary to an active lifestyle has been estimated as $£ 805$ (in terms of public sector health costs over a 20 year period) ${ }^{115}$ or, in other words, more than $£ 30$ billion for the segment of the United Kingdom population currently deemed physically inactive.

\subsection{Ecological consciousness and ecological conscience}

A further aspect of the importance of 'pedestrian democracy' lies embedded in the biological foundations of human behaviour, a perspective which, in turn, is intimately bound up with the place of humans within the ecological system which causes the natural world to cohere. Perhaps the most dominant insight of the last half-century has been a developing awareness of the interconnectedness of the entire physical and biological world. James Lovelock's 'Gaia thesis' emphasized an understanding of the earth as a self-sustaining homeostatic system 'acting in the manner of a single organism to sustain its own life'. ${ }^{116}$ Aldo Leopold had already spoken of the 'indivisibility of the earth ... as a living being' and of humanity as comprising merely part of a larger 'biotic community' of ecological equals. ${ }^{117}$

111. See Game Plan: a strategy for delivering Government's sport and physical activity objectives (Department for Culture, Media and Sport/Strategy Unit Report, December 2002). (Activity level was rated in 2002 at $32 \%$.)

112. Access to the Open Countryside in England and Wales (n 21), paras 1.8, 3.50, 3.66. 'Walking in the fresh air is one of the best forms of exercise for everyone' (ibid, para 3.67).

113. Scottish Executive, Draft Land Reform (Scotland) Bill (n 63), para 1.5.

114. Draft Marine Bill (Policy Paper) (n 16), Annex 4, Annex A3.1.

115. Ibid, Annex 4, para 31, Table 4.

116. J Lovelock, Gaia: a New Look at Life on Earth (OUP, New York 1979). See D Cosgrove, 'Landscapes and Myths, Gods and Humans' in B Bender (ed), Landscape: Politics and Perspectives (Berg Publishers, Providence RI 1993) 300.

117. A Leopold, 'Some Fundamentals of Conservation in the Southwest' (1923) in Flader and Callicott (eds) (n 6) 95. 
The 'deep ecology' of Arne Næss ${ }^{118}$ was likewise grounded in a recognition of the integral place of humankind within its environment and of the ecosystem as a network of multiple interconnections. The 'First Law of Ecology' is, indeed, that '[e]verything is connected to everything else'. ${ }^{119}$ To see landscape as a system is 'to penetrate the façade to discern a transect of pulsating flows, an immense energy exchange'. ${ }^{120}$

This holistic perception of the organic link between humans and their environment inevitably draws attention to the biosocial origins of human interaction with natural landscape. It also serves to uncover certain primal reactions to the environment as habitat. Deeply secreted in the unconscious biological memory is an understanding of land as a source of food and survival. From this elemental recognition arises an imperative need, in Aldo Leopold's phrase, ${ }^{121}$ to 'learn to read the land' - to be able to see and understand country. ${ }^{122}$ To go for a walk or to climb a rock face may not be simply an act of recreational exercise in the open air. It is to participate in some long forgotten, biosocially dictated search for food: it is a function of survival. ${ }^{123}$ In the primitive habitat the venture is deadly serious. It requires a 'highly sensitive apparatus for hazard-perception and hazardavoidance', key roles being played by 'the twin activities of seeing and hiding'. ${ }^{124}$ To 'see without being seen' ${ }^{125}$ becomes the ability to kill without being killed. In Jay Appleton's 'prospect-refuge' theory the desire for 'prospect' (or a vantage-point for viewing prey) is correlated with a need for 'refuge' (or a place of safety) as part of an inborn behaviour mechanism. ${ }^{126}$ Traversing landscape is a matter of managing risk, of conquering hazard, of pursuing and escaping. Exploration becomes a vital part of securing a mastery over the environment. Confidence in one's competence to negotiate large spaces is a necessary component of an ancient inherited strategy for survival. Even when the ability to orient successfully across natural terrain is no longer a prerequisite for biological survival, the mechanisms of survival 'do not die out immediately in the species but continue to be transmitted from one generation to another'. ${ }^{127}$

Evolutionary 'habitat theory' thus postulates that aesthetic pleasure in landscape is still derived 'from the observer experiencing an environment favourable to the satisfaction of his biological needs'. ${ }^{28}$ The primal attraction of 'prospect-dominant'

118. A Næss, 'The shallow and the deep, long-range ecology movement. A Summary' (1973) 16 Inquiry 95. See also B Devall and G Sessions, Deep Ecology (Gibbs M Smith Inc, Salt Lake City 1985).

119. B Commoner, The Closing Circle: Nature, Man, and Technology (Alfred A Knopf, New York 1972) 33.

120. DW Meinig, 'The Beholding Eye: Ten Versions of the Same Scene' in Meinig (ed) (n 84) 39.

121. A Leopold, 'Wherefore Wildlife Ecology?' (1947) in Flader and Callicott (eds) (n 6) 337. 122. Rachel Carson wrote poignantly of reading the landscape 'like the pages of an open book' (R Carson, Silent Spring (Ballantine, New York 1979) 27).

123. JD Porteous, 'Urban Environmental Aesthetics' in B Sadler and A Carlson (eds), Environmental Aesthetics: Essays in Interpretation (Department of Geography, University of Victoria, BC 1982) 69.

124. J Appleton, 'Pleasure and the Perception of Habitat: A Conceptual Framework' in B Sadler and A Carlson (eds) (n 123) 39-40.

125. K Lorenz, King Solomon's Ring (Meridian/Penguin Books, New York 1997) 193 (first published 1952).

126. J Appleton, The Experience of Landscape (revd edn, Wiley, Chichester 1996) 63-7.

127. Ibid 63 .

128. Ibid 66 . 
terrain may go far to explain enjoyment of a panoramic view across open country. ${ }^{129}$ The exhilaration of the vista from the mountain top may be analyzed, at least in part, as the modern sublimation of a biologically determined sensitivity to natural habitat. The desire to become lost in nature may be precisely that - a self-protective behaviour pattern inherited from our distant ancestors. Even the sensory satisfaction derived from proximity to inland water - for example, Wordsworth's Rydal Mere and 'long-loved Duddon'130 - is plausibly interpreted in terms of the human need to remain close to a constant supply of fresh water. ${ }^{131}$

Of course, these biosocial perceptions of recreational experience are scarcely reflected in any explicit form in the legislative history of access rights in Britain. Instead, the organic character of the nexus with landscape is compressed into rather tamer, bureaucratic language which advocates the benefits of a deeper 'understanding of the natural environment ${ }^{132}$ and of closer empathy with nature. The Land Reform (Scotland) Act 2003 recognizes, for example, that the access entitlement which it confers can encompass 'relevant educational activity', a phrase that is defined in terms of furtherance of the 'understanding of natural or cultural heritage'. ${ }^{133}$ More significantly, there has emerged some official awareness of the way in which people's enhanced 'understanding and appreciation of their environment ... is likely to encourage them to become more involved in its protection'. ${ }^{134}$

This link between ecological consciousness and ecological conscience is ultimately the most important rationale for the statutory recognition of 'pedestrian democracy'. Writing in the 1940s, Aldo Leopold believed that ' $[\mathrm{t}] \mathrm{o}$ promote perception is the only truly creative part of recreational engineering'. ${ }^{135}$ For Leopold, recreation was 'not the outdoors, but our reaction to it'. Recreational development was 'a job ... of building receptivity into the still unlovely human mind' ${ }^{136}$ In company with older cultures wiser than our own, ${ }^{137}$ Leopold saw land not as a commodity belonging to humans, but as 'a community to which we belong'. ${ }^{138}$ Accordingly, he defined the 'biotic community' as inclusive of 'soils, waters, plants, and animals, or collectively: the land'. ${ }^{139}$

129. The pleasure afforded by open parkland has been linked with the evident preference of early humans for 'open, grassy environments, with large herds of gregarious herbivores' (see KW Butzer, 'Environment, culture, and human evolution' (1977) 65(5) American Scientist 572, 579-80).

130. C Salvesen, The Landscape of Memory: A Study of Wordsworth's Poetry (Edward Arnold, London 1965) 199-200.

131. SC Bourassa, The Aesthetics of Landscape (Belhaven Press, London and New York 1991) 67-8.

132. Consultation on Proposals to improve access to the English coast (n 14), para 2.1; Draft Marine Bill (Policy Paper) (n 16), Annex 4, para 12; Marine and Coastal Access Bill Policy Document (n 16), para 15.

133. Land Reform (Scotland) Act 2003, s 1(3), (5).

134. Access to the Open Countryside in England and Wales (n 21), para 3.65.

135. 'Conservation Esthetic' in A Leopold, A Sand County Almanac (OUP, Oxford 1987) 173 (first published 1949).

136. Ibid 176-7.

137. Compare the recognition, within the Australian Aboriginal concept of land entitlement, 'that the clan belongs to the land [rather] than that the land belongs to the clan' (Milirrpum $v$ Nabalco Pty Ltd (1971) 17 FLR 141, 271). In relation to the overriding duty of the Aboriginal to 'look after country', see Gray (n 55) 181-8.

138. 'Foreword' in Leopold (n 135) viii.

139. 'The Land Ethic' in Leopold (n 135) 204. 
Leopold's impact upon all subsequent landscape philosophy is forever associated with his articulation of a 'land ethic' which requires that land, in the all-embracing sense of 'a community of interdependent parts', be 'loved and respected'. ${ }^{140}$ Landscape is not a domain lying beyond the boundaries of moral significance. The protection of nature is a moral concern; and for Leopold it was essential that there be an 'extension of the social conscience from people to land'. ${ }^{141}$ Leopold saw his 'land ethic', together with the 'ecological conscience' which underpinned it, as changing 'the role of Homo sapiens from conqueror of the land-community to plain member and citizen of it. It implies respect for his fellow-members, and also respect for the community as such'. ${ }^{142}$

Some three decades later even the sceptical John Passmore was inclined to agree that 'the West now needs not only a new concept of nature but a new set of moral principles to act as a guide in its relationships with nature'. ${ }^{143}$ Aldo Leopold's writings undoubtedly prepared the way for the emergence in the late 20th century of an extremely influential environmental movement ${ }^{144}$ (even if this movement is now multi-faceted rather than monolithic in character ${ }^{145}$ ). A substantial change in ethical outlook has occurred. It no longer seems strange to speak of the responsibilities of 'ecological citizenship'. ${ }^{146}$ There is today a wide acceptance of a 'new politics of obligation' - however imperfectly realized in practice - according to which 'human beings have obligations to animals, trees, mountains, oceans, and other members of the biotic community'. ${ }^{147}$ In an age of climate change and widespread environmental degradation, a global ontology that burdens all humans with duties towards planet

Earth is nowadays regarded as a vital key to human survival and well-being. ${ }^{148}$

\section{CONCLUSION}

In examining the subject of recreational access to scenic natural landscape, this paper has endeavoured to locate recent legislative initiatives in Britain within a wider context of environmental ethics. In introducing universal and generally indefeasible rights of public access to much of rural Britain, the Countryside and Rights of Way Act 2000 and the Land Reform (Scotland) Act 2003 represent quantum steps on the road toward 'pedestrian democracy'. The remarkable innovations brought about by these statutes are likely, in the near future, to be handsomely supplemented by a new Marine and Coastal Access Act.

140. 'A thing is right when it tends to preserve the integrity, stability, and beauty of the biotic community. It is wrong when it tends otherwise' (ibid 224-5).

141. Ibid 209. See also JB Callicott, 'The Conceptual Foundations of the Land Ethic' in Callicott (ed) (n 94) 196.

142. 'The Land Ethic' in Leopold (n 135) 204, 207. Leopold thought it 'inconceivable ... that an ethical relation to land can exist without love, respect, and admiration for land, and a high regard for its value ... in the philosophical sense' (ibid 223).

143. Passmore (n 89) 186.

144. Wallace Stegner described A Sand County Almanac as an 'almost holy book in conservation circles ... one of the prophetic books, the utterance of an American Isaiah' (Stegner, 'The Legacy of Aldo Leopold' in Callicott (ed) (n 94) 233).

145. CD Stone, 'Is Environmentalism Dead?' (2008) 38 Envtl Law 19, 24.

146. Dobson (n 68) 83-140; J Bendik-Keymer, The Ecological Life: Discovering Citizenship and a Sense of Humanity (Rowman and Littlefield, New York 2006) 99.

147. MJ Smith, Ecologism: Towards Ecological Citizenship (Open University Press, Buckingham 1998) 99.

148. See H Rolston III, 'Duties to Ecosystems' in Callicott (ed) (n 94) 246. 
Of course, challenges and difficulties remain. The call for open access will inevitably extend to woodland, rivers and other inland water. Much of the mapping process which underlies the CROW Act is flawed and, indeed, the very methodology of mapping is arguably misconceived. At the time of writing, Parliament has yet to finalize the detailed provisions relating to coastal access and the process for determining the line of the 'coastal route'. ${ }^{149}$ Vexed problems will arise, in particular, in connection with the privacy concerns of those landowners affected by any proposed access route. ${ }^{150}$ There has also been much debate about whether the Marine and Coastal Access Bill provides an appeal mechanism sufficiently robust to ward off a 'fair hearing' challenge pursuant to Article 6 of the European Convention on Human Rights. ${ }^{151}$

Not the least difficult issue involved in the extension of 'pedestrian democracy' centres on the question whether monetary compensation can be claimed by landowners who are compulsorily subjected to the intrusion of recreational visitors. Neither the CROW Act 2000 nor its Scots analogue contains any general provision for compensation, a stance likely to be replicated under the imminent coastal access legislation. Some time ago the government announced 'a working presumption' against paying compensation, taking the view that coastal access should be 'open to all and free at the point of use', ${ }^{152}$ any adverse impact on landowners being minimized by 'locally sensitive alignment of the access corridor'. ${ }^{153}$ Space does not permit any more expansive analysis of the problem here, save to say that the European approach to such matters does not normally favour any requirement of money compensation in cases of mandatory recreational access to privately held land. ${ }^{154}$ This bias against the provision of indemnity contrasts sharply with the predominant view in the United States that even 'a strong public desire to improve the public condition is not enough to warrant achieving the desire by a shorter cut than the constitutional way of paying for the change'. ${ }^{155}$ Thus American courts have held that governmental attempts to require public access to private property are unconstitutional and invalid 'unless the government first follows the condemnation process and pays just compensation'. ${ }^{156}$ A live issue in the United States is now the question whether any compensable taking of property occurs when obsolete railroad easements over privately owned land are compulsorily converted by statute into

149. The Marine and Coastal Access Bill completed its passage through the House of Commons committee stage on 14 July 2009 and was due to continue to the next stages of Report and Third Reading in the Commons in October 2009.

150. The Marine and Coastal Access Bill requires, in delphic but conventional fashion, that a 'fair balance' be struck between 'the interests of the public in having rights of access over land and the interests of any person with a relevant interest in the land' (cl 292(3)).

151. See House of Lords and House of Commons Joint Committee on Human Rights, Legislative Scrutiny: Marine and Coastal Access Bill; Government Response to the Committee's Thirteenth Report of Session 2008-09 (HL Paper 142/HC 918, 14 July 2009), paras 1.1-1.10. 152. Draft Marine Bill (Policy Paper) (n 16), Annex 4, para 11.

153. Consultation on Proposals to improve access to the English coast (n 14) para 8.3. DEFRA indicated (ibid) that, in view of the likely provision of grant aid to landowners and farmers for environmental improvements around the coast, it was inferable that 'there should be few if any instances where compensation might be payable.'

154. Banér v Sweden (1989) 60 DR 128, 140, 142; Huber, Staufer, Staufer, Sportanglerbund Völklabruck \& Eckhardt v Austria (1996) 22 EHRR CD 91. See ECHR Protocol No 1, Art 1. 155. Pennsylvania Coal Co v Mahon 260 US 393, 416, 67 L Ed 322, 326 (1922) (Holmes J). 156. State of Alaska v Arnariak 941 P2d 154, 156 (1997). See Nollan v California Coastal Commission 483 US 825, 831, 97 L Ed 2d 677, 685 (1987); Dolan v City of Tigard 512 US 374, 384, 129 L Ed 2d 304, 316 (1994). 
hiking trails for use by the public. Although the 'rails-to-trails' movement has claimed that abandoned rail corridors through scenic terrain offer a unique opportunity for a second wave of national park creation, the judicial response so far has been to insist that the element of public interest that validated the original requisition of railroad easements cannot now justify an uncompensated shift to public recreational use. ${ }^{157}$

Divergences of view - such as those evident in relation to the question of compensation for mandatory recreational access - should not distract attention from the uniquely ethical issues which underlie the expansion of access opportunities. Indeed, it may be said that these differences of approach are indicative of varying degrees of philosophical commitment to the goal of environmental welfare. Recreational access rights in the United States have not received the same degree of recognition or protection as is provided by current British legislation. ${ }^{158}$ In the United Kingdom the emergence of enhanced entitlements of entry to privately owned natural landscape has largely been premised - albeit in the oblique and lifeless language of government bureaucrats - upon broad imperatives of greater public engagement with, and more conscious stewardship of, the natural environment. Part of the responsibility inherent in ecological citizenship comprises an obligation to live in harmony with the remainder of our biotic community. Like nothing else, the modern environmental movement has endorsed a major ideological shift away from the 'arrogance of rights' toward the 'consonance of duties'. ${ }^{159}$

But rights are not irrelevant. In Britain the silent reciprocal of the citizen's heightened responsibility to care for land has been a dramatic intensification of the public entitlement to derive enjoyment from land. The human obligation to 'look after country' finds its complement in a human right of access to nature and to the recreational amenity afforded by wild or open spaces. ${ }^{160}$ In some new variant of the social contract, the requirement to coexist in ecological harmony carries an implied quid pro quo in the form of greater participation in the environmental goods of life. ${ }^{161}$ Correlatively, the modern drive toward 'pedestrian democracy' has emerged as an integral component of the social acculturation process on which any hope of long-term environmental welfare may depend. Connection as of right with the wilder portions of our earthscape has now become a very real part of the 'geography of hope' so memorably identified by Wallace Stegner.

Postscript On 12 November 2009, some time after the submission of this paper for publication, the Marine and Coastal Access Bill 2009 completed its parliamentary passage and received the royal assent.

157. Preseault v US 100 F3d 1525 (1996); Hash v US 403 F3d 1308 (Fed Cir 2005); Blendu v US 75 Fed Cl 543 (2007); Ellamae Phillips Co v US 564 F3d 1367 (2009).

158. See Anderson (n 25) 417-30. See also JG Sprankling, 'The Antiwilderness Bias in American Property Law' (1996) 63 U Chi L Rev 519.

159. The phrases are those of Bertrand de Jouvenel, written long before the modern awakening of environmental awareness in Europe. See JF Huntington (tr), Sovereignty: an inquiry into the political good (CUP, Cambridge 1957) 202.

160. It need hardly be said that human rights are not a proper subject of cash transaction. On this analysis, the imposition of compulsory recreational access carries no right to money compensation for the affected landowner, whose pay-off (if required) is met, in all but the most unusual circumstances, by the 'average reciprocity of advantage' implicit in the access scheme.

161. This is not to imply that, in the context of recreational access to natural terrain, entitlements are unlimited by considerations of reasonable user. Excessive exercise of rights (eg by large numbers of people) may pose a substantial menace to environmental conservation and require the imposition of management strategies (see CM Rose, 'Rethinking Environmental Controls: Management Strategies for Common Resources’ (1991) Duke LJ 1). 